Research Article

\title{
A study to estimate the prevalence of depression among the inmates of select old age homes in Bangalore city, India
}

\author{
Karthik C.*, Viswanatha P. G., Shobha, Ranganath T. S., Sushmitha P.
}

Department of Community Medicine, Bangalore Medical College and Research Institute, Fort, Bangalore, Karnataka, India

Received: 11 May 2016

Accepted: 04 June 2016

*Correspondence:

Dr. Karthik C.,

E-mail: drkarthikslm04@gmail.com

Copyright: (c) the author(s), publisher and licensee Medip Academy. This is an open-access article distributed under the terms of the Creative Commons Attribution Non-Commercial License, which permits unrestricted non-commercial use, distribution, and reproduction in any medium, provided the original work is properly cited.

\begin{abstract}
Background: Geriatrics deals with the provision of comprehensive care that is given in the clinical, preventive, remedial and social aspects of illness in the elderly. As the age advances beyond 60, the person is subjected to emotional turmoil due to varying factors as a result of which they undergo a phase of depressive illness. The purpose of this study was to estimate the prevalence of depression among the inmates of select old age homes in Bangalore city, using geriatric depression scale (GDS).

Methods: It is a cross sectional study conducted among the inmates (330) in select old age homes in Bangalore city based on a 15-item geriatric depression scale (Short Form) during the period July 2014 to October 2014.

Results: A vast majority, 207 (62.73\%) were found to have secured scores between 6 and 10 which is suggestive of depressive syndrome among them. 66 (20\%) of them were found to be actually depressed with scores 11 and above. $57(17.27 \%)$ of them were not depressed.

Conclusions: This revealed a sad state of the psychological trauma that they go through due to abandonment by their kith and kin. The mutual disregard and the lack of concern that their families had shown had also torn down their spirits and left them with a battered soul.
\end{abstract}

Keywords: Geriatrics, Homes, Depression, Neglect

\section{INTRODUCTION}

Globally, the population is ageing rapidly. Between 2015 and 2050, the proportion of the world's population over 60 years will nearly double, from $12 \%$ to $22 \%$. Mental health and emotional well-being are as important in older age as at any other time of life. Neuropsychiatric disorders among the older adults account for $6.6 \%$ of the total disability (DALYs) for this age group. ${ }^{1}$

The care of the aged is called clinical gerontology or geriatrics and it deals with the provision of comprehensive care that is given in the clinical, preventive, remedial and social aspects of illness that occur among them. ${ }^{2}$ As the age advances beyond 60 the person is subjected to emotional turmoil due to social maladjustment as a result of which they undergo a phase of depressive illness. The key features of depression are depressive mood which includes pervasive sadness and persistent sadness and depressive ideations which in turn includes hopelessness, helplessness and worthlessness. ${ }^{3}$ It can extend to become a multisystem disorder with physiological, biological and psychomotor changes.

Over $20 \%$ of adults aged 60 and over suffer from a mental or neurological disorder (excluding headache disorders) in which unipolar depression occurs in $7 \%$ of the general elderly population. Depression is both 
underdiagnosed and undertreated in primary care settings. Symptoms of depression in older adults are often overlooked and untreated because they coincide with other problems encountered by older adults. ${ }^{1}$

The purpose of this study was to detect elderly patients in depression among the inmates of selected old age homes in Bangalore city, using a 15 item Geriatric Depression Scale (GDS). ${ }^{4,5}$

Objectives of the study was to estimate the prevalence of depression among the inmates of select old age homes in Bangalore city.

\section{METHODS}

Study design: Cross sectional study.

Study area: Select old age homes in Bangalore city.

Study population: All the inmates of select old age homes in Bangalore city with study participants consisting of consenting elderly (> 60 years old).

Inclusion criteria: People among the study population who gave consent for the study.

Exclusion criteria: People who are deaf and dumb, the non-responsive ones and those who are not willing to take part in the study.

Sample size: Using formula $4 \mathrm{pq} / \mathrm{d}^{2}$, according to a previous study done by Kritiotis L8 on prevalence of depression among elderly, the prevalence $\mathrm{p}$ was taken to be $25 \%, q=100-p=75$, $d$ i.e., absolute precision is taken as 5 .

Hence $4 \mathrm{pq} / \mathrm{d}^{2}=4 \times 25 \times 75 / 52=7500 / 25=300$.

So the sample size is 300 and $10 \%$ were included to the sample size to avoid bias due to non-responsiveness. i.e., 30 were added to the actual sample.

Therefore the sample size is $300+30=330$.

Sampling method: Each old home, on an average had about 25 inmates. From 98 old age homes, 14 such homes were selected by simple random sampling method and all the inmates were questioned using the 15-item short form GDS questionnaire. $10 \%$ were included to the sample size to avoid bias due to non-responsiveness.

Assessment tool: The interview was conducted in the language with which the subject was familiar (Kannada/Tamil), for which purpose the consent form and assessment tools were translated into both the languages and back-translated by an independent coworker proficient in both languages to ensure validity of the translation. Depression was assessed using the 15item Geriatric Depression Scale (GDS), which is a 15- item self-report assessment used as a basic screening measure of depression in the elderly. Accuracy of the GDS-15 is not influenced by the severity of medical burden, age, or other socio-demographic characteristics and even the very old and ill can be screened appropriately.

Study duration: 6 months extending from July 2014 to December 2014.

Statistical analysis: The data was collected and compiled in MS Excel and analyzed by using Statistical Package for Social Sciences (SPSS) software version 20.0.Descriptive statistics was used as necessary, all qualitative variables were presented as frequency and percentages.

\section{RESULTS}

Of the total 330 people who were questioned 219 $(66.40 \%)$ were males and $111(33.60 \%)$ were females. This reveals a majority of the study population were males who were shunned from households and admitted in old age homes due to varying reasons.

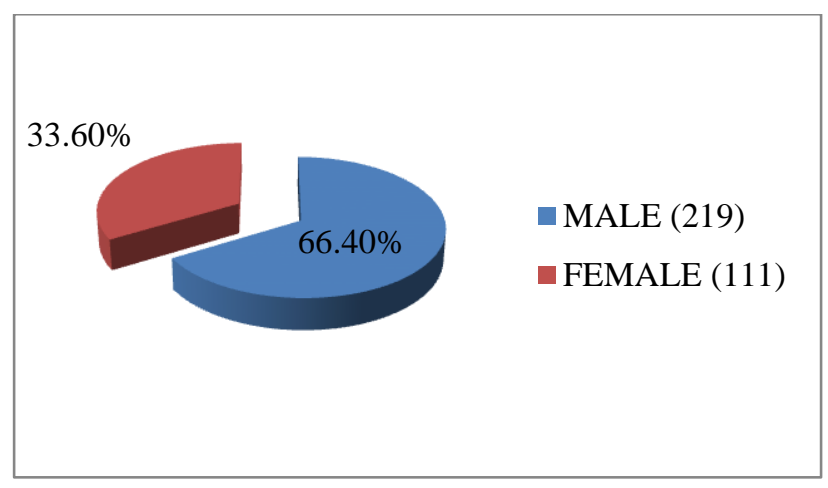

Figure 1: Sex distribution.

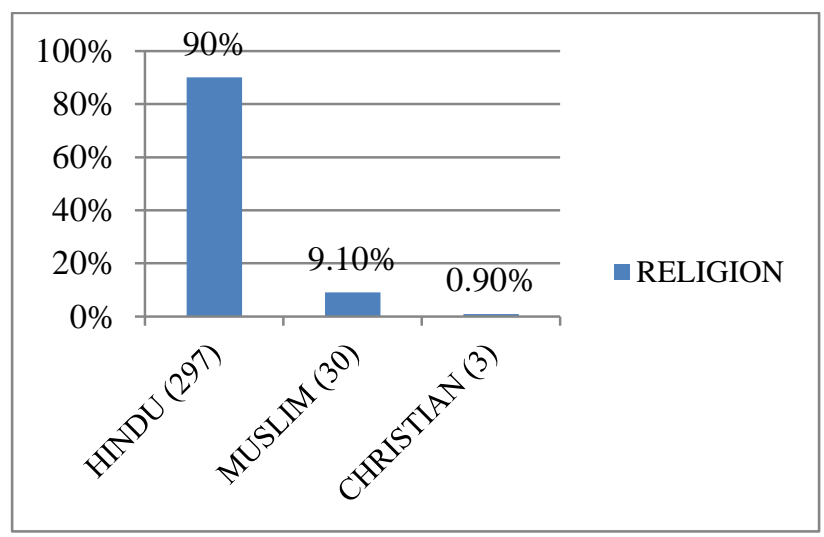

Figure 2: Religion wise distribution of the study population.

Figure 2 reveals that the majority of the inmates 297 (90\%) were Hindus followed by $30(9.09 \%)$ Muslims and $3(0.91 \%)$ Christians. The predominance of Hindus 
among the study population is because of the fact, that some old age homes selectively imbibe inmates on religious grounds. Hence this skewing of data towards Hindus, cannot be interpreted that a greater degree of neglect and abandonment prevails among Hindu families.

Table 1: Geriatric depression scale (GDS).

\begin{tabular}{|c|c|c|}
\hline Questions & $\begin{array}{l}\text { Answers } \\
\text { given } \\
\text { yes/no } * *\end{array}$ & $\begin{array}{l}\text { Percentage } \\
(\%)\end{array}$ \\
\hline $\begin{array}{l}\text { Are you basically satisfied } \\
\text { with your life? }\end{array}$ & Yes/NO & $43.6 \%$ \\
\hline $\begin{array}{l}\text { Have you dropped many } \\
\text { of your activities and } \\
\text { interests? }\end{array}$ & Yes/No & $59.1 \%$ \\
\hline $\begin{array}{l}\text { Do you feel that your life } \\
\text { is empty? }\end{array}$ & Yes/No & $42.7 \%$ \\
\hline Do you often get bored? & Yes/No & $50 \%$ \\
\hline $\begin{array}{l}\text { Are you in good spirits } \\
\text { most of the times? }\end{array}$ & Yes/NO & $40.9 \%$ \\
\hline $\begin{array}{l}\text { Are you afraid that } \\
\text { something bad is going to } \\
\text { happen to you? }\end{array}$ & Yes/No & $56.4 \%$ \\
\hline $\begin{array}{l}\text { Do you feel happy most of } \\
\text { the time? }\end{array}$ & Yes/No & $40 . \%$ \\
\hline $\begin{array}{l}\text { Do you often feel } \\
\text { helpless? }\end{array}$ & Yes/No & $54.5 \%$ \\
\hline $\begin{array}{l}\text { Do you prefer to stay at } \\
\text { home rather than going } \\
\text { out } \& \text { doing new things? }\end{array}$ & Yes/No & $50 \%$ \\
\hline $\begin{array}{l}\text { Do you feel that you have } \\
\text { more memory problems } \\
\text { than others? }\end{array}$ & Yes/No & $48.2 \%$ \\
\hline $\begin{array}{l}\text { Do you feel that it is } \\
\text { wonderful to be alive } \\
\text { now? }\end{array}$ & Yes/No & $45.5 \%$ \\
\hline $\begin{array}{l}\text { Do you feel pretty } \\
\text { worthless the way you are } \\
\text { now? }\end{array}$ & Yes/No & $55.5 \%$ \\
\hline $\begin{array}{l}\text { Do you feel full of } \\
\text { energy? }\end{array}$ & Yes/No & $38.2 \%$ \\
\hline $\begin{array}{l}\text { Do you feel that your } \\
\text { situation is hopeless? }\end{array}$ & Yes/No & $52.7 \%$ \\
\hline $\begin{array}{l}\text { Do you think that most } \\
\text { people are better off than } \\
\text { you are? }\end{array}$ & Yes/No & $44.5 \%$ \\
\hline \multicolumn{3}{|c|}{$\begin{array}{l}\text { *In cases of time constraints the Five-item version of the GDS: } \\
\text { Questions } 1,4,8,9,12 \text { can be used, **The capitalized answers } \\
\text { are take into consideration as an indication of depression and } \\
\text { scores of } 0-15 \text { are given to each subject based on the number of } \\
\text { these capitalized answers, }<5=\text { No depression, } 5-10= \\
\text { Suggestive of depressive syndrome, }>10=\text { Depression. }\end{array}$} \\
\hline
\end{tabular}

The assessment of depression is based on the 15 point questionnaire as shown in the Table 1. The 5 point version of the same which includes answers to the questions 1, 4, 8, 9 and 12, are sufficient enough to be used to diagnose depression in cases of time constraints.
The percentage represents the average of the capitalized answers given by the 110 subjects under study. 7 out of the 15 questions namely, 2, 4, 6, 8, 9, 12 and 14 had received more than $50 \%$ capitalized answers which is indicative of a great deal of depression among the inmates. This reveals that $59.1 \%$ have dropped many of their activities and interests. $56.4 \%$ are afraid that something bad is going to happen to them. $55.5 \%$ of them feel worthless the way they are now and $54.5 \%$ often feel helpless. 52.4\% feel hopeless. The last 3 common type of depressive ideas namely worthlessness, helplessness and hopelessness reveals the high degree of pessimism that prevails among them. It is an obvious fact that $50 \%$ were found to be bored with life, given the solitude and monotony of a secluded life living among a similar age cohort deprived of the privileges of a social familial atmosphere. Nevertheless many $(43.6 \%)$ were found to be basically satisfied with their life and in good spirits $(40.6 \%)$, with a sense of fullness $(42.7 \%)$ and energy $(38.2 \%)$. Some $(45.5 \%)$ found it to be wonderful to be still alive and were better off than others (44.5\%). Considering the age and the related depreciation in cognitive functions quite a few had problems with memory.

Table 2 reveals the score-wise distribution of the inmates. The scores were based on the answers to the 15 point question. A vast majority, $207(62.73 \%)$ were found to have secured scores between 6 and 10 which is suggestive of depressive syndrome among them. 66 (20\%) of them were found to be actually depressed with scores 11 and above. $57(17.27 \%)$ of them were not depressed.

Table 2: Score-wise distribution of the inmates.

\begin{tabular}{|lll|}
\hline Class interval & Numbers & Percentage \\
\hline $0-5$ & 57 & $17.27 \%$ \\
\hline $6-10$ & 207 & $62.73 \%$ \\
\hline $11-15$ & 66 & $20 \%$ \\
\hline
\end{tabular}

\section{DISCUSSION}

A meta-analysis of 74 studies, including 487,275 elderly individuals found the worldwide prevalence rate of depressive disorders to be between 4.7 to $16 \%$. This study indicates a comparatively higher prevalence of geriatric depression in India $(21.9 \%){ }^{6}$ The Chennai Urban Rural Epidemiology study (CURES) for which twenty thousand and one individuals were recruited for the study, with the subjects of the urban component of the CURES recruited from within the corporation limits of Chennai City showed the prevalence of depression among population over 20 years as $15.1 \% .^{7}$ Studies in primary care settings point to a higher prevalence of depressive disorders amongst the elderly (with chronic co-morbid diseases), ranging from 10 to $25 \% .^{8}$ A crosssectional study in a tertiary care hospital in Karachi found the prevalence of depression to be $19.5 \%$ in the elderly aged 65 years and above. ${ }^{9}$ The prevalence has been 
reported to be $29.36 \%$ in the urban slums of Dharwad district, Karnataka. ${ }^{10}$

In this study involving 330 elderly inmates of select old age homes in Bangalore city, the prevalence of depression was found to be $20 \%$ with $62.3 \%$ of the study population showing symptoms suggestive of depression. The $20 \%$ is comparable to the national numbers of $21.9 \%$ of prevalence of depression that prevails among geriatric population. $^{11}$

\section{CONCLUSION}

$62.73 \%$ had symptoms suggestive of depression and $20 \%$ were found to have depressive illness. This revealed a sad state of the psychological trauma that they undergo due to abandonment by their kith and kin. The mutual disregard and the lack of concern that their families had shown had also torn down their spirits and left them with a battered soul.

\section{ACKNOWLEDGEMENTS}

Authors would like to acknowledge the contributions made by the faculty of the Department of Community Medicine, Bangalore Medical College and Research Institute (BMCRI) towards the conduct of my study. I also acknowledge the help rendered by the staff and the inmates of the old homes in which the study was conducted.

Funding: No funding sources Conflict of interest: None declared

Ethical approval: The study was approved by the Institutional Ethics Committee

\section{REFERENCES}

1. World Health Organization. WHO fact sheet: Mental health and older adults. Updated April 2016. Available at: http://www.who.int/ mediacentre/ factsheets/fs381/en/.

2. Park K. Park's text book of preventive and social medicine. $23^{\text {rd }}$ ed. Jabalpur. Banarsidas bhanot; 2015:276.
3. Ahuja N. A short textbook of psychiatry. $7^{\text {th }}$ ed. New Delhi: Jaypee Brothers Medical Publishers; 2011:72.

4. Yesavage JA, Brink TL, Rose TL, Lum O, Huang V, Adey M, Leirer VO. Development and validation of a geriatric depression rating scale: a preliminary report. J Psych Res. 1983;17:37-49.

5. Sheikh JI, Yesavage JA. Geriatric depression scale: recent evidence and development of a shorter version. Clin Gerontol. 1986;5:165-72.

6. Barua A, Ghosh MK, Kar N, Basilio MA. Prevalence of depressive disorders in the elderly. Ann Saudi Med. 2011;31(6):620-4.

7. Poongothai H, Pradeepa R, Ganesan A, Mohan V. Prevalence of depression in a large urban South Indian population - The Chennai Urban Rural Epidemiology study (CURES - 70). PLoS One. 2009;4:e7185. Accessed on Dec 25, 2012. Available at:http://www.plosone.org/article/info:doi/10.1371/j ournal.pone.0007185.

8. Kritiotis L. Depressive disorders and chronic comorbid disease states: a pharmacoepidemiological evaluation. magister scientiae. Nelson Mandela Metropolitan University. 2007. Accessed on $25^{\text {th }}$ February 2012. Available at: http://dspace.nmmu.ac.za:8080/jspui/bitstream/1094 8/653/1/LIA\%20KRITIOTIS.pdf.

9. Taqui AM, Itrat A, Qidwai W, Qadri Z. Depression in the elderly: does family system play a role? A cross-sectional study. BMC Psychiatry. 2007;7:57.

10. Pracheth R, Mayur SS, Chowti JV. Geriatric Depression Scale: A tool to assess depression in elderly. Int J Med Sci Public Health. 2013;2:31-5.

11. Kishore J. National health programs of India. $11^{\text {th }}$ ed. New Delhi: Century Publications; chapter 8; 2014:444.

Cite this article as: Karthik C, Viswanatha PG, Shobha, Ranganath TS, Sushmitha P. A study to estimate the prevalence of depression among the inmates of select old age homes in Bangalore city, India. Int J Community Med Public Health 2016;3:1803-6. 